\title{
The challenges of developing an irrigation strategy for UK agriculture and horticulture in 2020: industry and research priorities
}

\author{
Knox, J.W. ${ }^{1,}$, Kay, M.G. ${ }^{2}$, Hess, T.M. ${ }^{1}$, and Holman, I.P. ${ }^{1}$ \\ ${ }^{1}$ Cranfield Water Science Institute, Cranfield University, Bedfordshire, MK43 OAL, UK \\ ${ }^{2}$ RTCS Ltd., Rushden, Northants NN10 6AG, UK
}

*Corresponding author: j.knox@ cranfield.ac.uk

\begin{abstract}
In many countries, including the UK, water resources are under intense stress with recent droughts highlighting the risks to the security of supplies for different sectors including domestic water supply, industry, agriculture (including horticulture), power generation and the environment. A changing climate with greater rainfall uncertainty, coupled with new regulations, increasing competition for water and demands for sustainable development will only exacerbate the current situation, with major supply-demand imbalances expected over the next few decades. In the UK, irrigated agriculture constitutes a volumetrically small but economically high value use of water, to maximise crop yields and quality. However, the importance of irrigation is also changing, driven by the intensification and transformation of the agricultural sector, the need to recognise water as an 'essential' use, policy incentives to increase domestic food production, and an industry imperative to increase water use efficiency ${ }^{1}$ and ensure agricultural expansion can continue to underpin the rural economy. This review considers the key climate and water-related risks facing the agricultural and horticultural crop sectors, the various environmental, regulatory and business externalities or 'drivers for change', and the strategic priorities for action, both from industry and research perspectives.
\end{abstract}

Keywords: Drought; environment; irrigation; regulation, water resources.

\section{Introduction}

Agriculture (including horticulture) is the largest global user of water, accounting for $70 \%$ of all freshwater withdrawals. However, reconciling this allocation of water to meet the burgeoning food demands for a growing population against concerns regarding increasing water scarcity remains a serious global policy dilemma (Grafton et al., 2018). Agriculture is also the most drought-sensitive economic sector and highly vulnerable to increases in climate variability (Wilhite, 2007). In spite of this, few countries, particularly those facing water scarcity, have established agricultural water strategies as part of their overall water resources planning (UN, 2018), focusing instead on domestic water supplies and to some extent on environmental flow requirements. Many countries simply do not yet have the means for collecting and processing the data needed, using it to underpin development of policy and strategies for water use, and the capacity to implement the strategy (UN, 2018). The UK does not have an agricultural water strategy, for various reasons it too lacks national data collection and processing. Agricultural planning is left to farmers and the market, as most cropping is rainfed in a country that is generally perceived to be 'wet' and so does not rely extensively on irrigated agriculture. But rainfall varies significantly across the country, both seasonally and

\footnotetext{
${ }^{1}$ We recognise that the terms 'water use efficiency' and 'irrigation efficiency' have been, and continue to be, a subject of much misunderstanding and debate with many different definitions emerging as a result. Abstraction licence applications in the UK ask that farmers irrigate efficiently, although this has never been properly defined. The term is still endemic in the literature. Suffice to say that we use it in this paper in the general sense of making the best use of available water for producing crops and, from a farmer's point of view, ensuring that water they abstract for irrigation is consumed by the crop and is not wasted unnecessarily (Knox, et al., 2012).
} 
annually (Met Office, 2020) and in order to deal with the capricious nature of summer rainfall, many farming enterprises use supplemental irrigation during periods of rainfall deficit to maximise crop yields and for quality assurance to deliver consistent supplies of premium quality produce for the major processors and retailers. Although irrigation typically represents only $1 \%$ of water withdrawals in England and Wales (Knox et al., 2013), Rey et al. (2016) estimated farm-level financial net benefits of irrigation in a dry year to be more than $£ 650$ million.

Irrigated agriculture and horticulture therefore form an integral part of the UK rural economy, particularly in the drier Midlands, East, and Southeast England. More than 1,000 agribusinesses, large and small, depend on irrigation to produce high quality fruit and vegetables for the nation's wholesalers, supermarkets, and food service sectors. However, concerns are growing over water allocations, increasing demands and competition among water-dependent sectors. Although the UK has a well-developed strategy for protecting public water supplies, and is developing a strategy for water and the environment, it has yet to develop a comprehensive water strategy for agriculture and horticulture. The questions asked of public water supply, such as how much water is needed now and in the future, and what investment is required to increase water security, have not been asked about water needs for irrigated agriculture. Unlike, public water supply companies, which have statutory duties set by government, irrigated agriculture is in the hands of the private sector (although tightly regulated by government). This is a fragmented industry with no focal organisation that has responsibility, resources and capacity to identify the priorities and drive change. Therefore a strategy is urgently needed to ensure that irrigated agriculture receives a fair share of the nation's water resources as the UK government makes plans for an integrated approach to water resources management in line with the requirements of the 2030 UN Development Agenda for Sustainable Development (UN, 2018).

This paper reviews the water-related risks to UK agriculture and horticulture, and identifies strategic industry and research priorities as the foundation for establishing a national water strategy for irrigated agriculture. The review draws on evidence published in the scientific literature as well as information gathered through interviews, meetings and technical workshops held with key informants and agricultural stakeholders between 2018 and 2020, as part of a broader national research programme (https://aboutdrought.info/) to assess drought risks and impacts on the UK economy including agriculture. Since much of the industry evidence was qualitative, this was collated and presented as a narrative assessment, rather than adopting a more formalised quantitative approach. However, the synthesis of evidence has been subjected to industrial feedback and review to help validate the reported opinions from the selected key informants.

This review coordinates thinking among the various organisations involved in irrigation, and attempts to answer the question: 'how much water will irrigated agriculture need in future?' bearing in mind the uncertainties of the UK climate, the potential impacts of climate change, the uncertainties over future food and trade policies, new water regulations governing sustainable abstractions, and a growing population with changing diets.

\section{Irrigated agriculture in UK}

Irrigated agriculture helps 'add value' to the UK agrifood industry, which is the UK's largest manufacturing sector with over 6,600 food and drink businesses sourcing their produce from UK farms. This industry is worth $£ 112$ billion to the economy ( $8 \%$ of total), employs $>3.6$ million people (14\% of total), accounts for $19 \%$ of the UK's total manufacturing turnover and buys two-thirds of the UK's agricultural and horticultural produce (WfFG, 2018). Beyond the farm-gate, many businesses service this industry. They provide equipment and farm supplies, 
post-harvest processing and packaging, marketing services, transport, and distribution. For example, in the Fens region in Eastern England, agricultural production contributes $£ 34$ billion per year to the UK's Gross Value Added (GVA), sustains $>150,000$ jobs and provides $18 \%$ of national farm-gate output (NFU, 2019).

Water is at the heart of this industry, arguably one of the most sophisticated food markets in the world. Yet, nearly three quarters of the volume licensed for agricultural spray irrigation is located within catchments where there is insufficient water to meet all the demand in a dry year. Recent droughts (Rey et al., 2017; Barker et al., 2019) and the longer-term threat of climate change, with hotter, drier summers, reduced water availability (Afzal and Ragab, 2019; Rahiz and New, 2013) and increasing water demand (Sharmina et al., 2016) only heighten concerns about the reliability of future supplies for irrigated agriculture (Rio et al., 2018). It is important to note that under existing water resources legislation, trickle (or drip) irrigation in the UK has historically been exempt from requiring a licence to abstract water for crop irrigation because it was not in use when abstraction legislation was established in the 1960s. The water regulator has therefore had no control over the location and volumes of water abstracted for trickle irrigation. However, that situation changed in 2018 with new regulation bringing trickle irrigation into the new licensing regime. Transitional arrangements are currently in force with new authorisations for trickle being released in 2022. This will mean all irrigation abstractions, irrespective of the method of application, will then be controlled.

During periods of water shortage, abstraction for domestic use, industry, and the environment generally take precedence. Coupled with uncertainties about changes in the way water may be allocated in future, many farm businesses are reluctant to invest in irrigation infrastructure for the long-term. Droughts and water scarcity thus threaten the sustainability of irrigated agriculture and the livelihoods it supports.

Following the severe 1976 drought (Burke et al., 2010; Royal Society 1978), Sir Nigel Strutt advised the UK Government on the future water needs for agriculture and horticulture and the measures needed to promote water use efficiency (ACAH, 1978). At that time, irrigated agriculture in the UK was in its infancy, but the drought was a wake-up call for the industry. Farmers responded by investing in irrigation equipment and on-farm storage with assistance from government subsidies. The industry also formed the UK Irrigation Association (UKIA) (www.ukia.org) an independent organisation to promote better understanding of the principles and practices of irrigation. Since the Strutt Report, major changes have also taken place in the sector, including substantial growth in irrigation driven by concerns about future droughts (Rey et al., 2017; Wreford and Adger, 2010), but increasingly by market and retailer demands for quality assurance (these include grower protocols linked to established environmental, social and welfare standards such as the Red Tractor, Nature's Choice, and Field to Fork). The government is also encouraging the food and farming sector to increase productivity through sustainable intensification and to expand markets both nationally and internationally (Defra, 2020a). There is thus significant potential for growth and opportunities for the rural economy, but uncertainties over future water supplies (availability, reliability, and quality) will have important consequences for irrigated farming and could act as disincentives or constraints on future growth and investment.

Irrigated agriculture in the UK faces unprecedented threats from water shortage, exacerbated by rising competition from other water users. In some catchments, withdrawals are already causing a shortage of water to sustain the environment (over-abstracted). In others, damage would be caused if all users withdrew the amount they were allowed to (over-licensed) (Weatherhead and Howden, 2009). Ongoing water regulation and legislative reforms (Defra 
2011, 2019), more frequent droughts and climate change are also highlighting limitations on existing supplies. After a spate of average to relatively 'wet' summers in England, the heatwave in 2018 (McCarthy et al., 2019) highlighted the significant agronomic and economic importance of water for agricultural irrigation and the risks to production. For example, using an aridity indicator, Figure 1 shows how the aridity varied between a typically 'wet' year (2012), an 'average' year (2016) and extreme dry year (1976) for a representative site at Cambridge in the east of England. The indicator is based on the "potential soil moisture deficit' which represents the cumulative daily balance between the input of rainfall and the output of reference evapotranspiration (ETo). The indicator is strongly correlated to irrigation need and has been widely used internationally to assess agroclimatic variability (RodriguezDiaz et al., 2007; De Silva et al., 2007). The data show that 2018 was similar to 1976 with virtually no rainfall during the main growing season between 01 May and 30 July. For many irrigators, this put extreme stress on peak abstraction rates and highlighted major constraints in irrigation infrastructure. Peak demand for different crops also occurred simultaneously creating problems for prioritising irrigation. Many growers used all their licensed allocation and sought additional water via emergency trades. These experiences have understandably raised questions regarding to what extent the agri-food sector learnt lessons from 2018, and whether it will be better prepared for the next drought event. It also highlights the challenges for water resource planners in managing and allocating water for agricultural irrigation when there is such large spatial and temporal variability in demand.

\section{Outdoor and protected cropping}

There are two important irrigation sub-sectors: outdoor field-scale production and indoor (protected) cropping (Table 1). For outdoor cropping, irrigation is supplemental to rainfall so theoretical (unconstrained) annual demand depends on a range of factors, including local soil water-holding characteristics, summer agroclimate (rainfall and ET) and the target market for the produce, as this strongly influences crop quality criteria. Outdoor irrigation relies on abstraction from surface or ground water, which is subject to licence conditions. Most licences issued for spray irrigation are now time-limited which states that abstraction has to stop when river flows fall below a certain threshold level (so-called 'Hands-off Flow'). Restrictions can be temporary (days) or longer (weeks) depending on the period over which the drought conditions impact on river flows. Irrigation is also generally needed at times when water resources are most constrained. Hence, understanding the factors that influence water use, where demand 'hotspots' might occur, and identifying the 'drivers of change' are important in quantifying future spatial and temporal changes in irrigation demand.

In contrast, for protected crops grown under polytunnels or in glasshouses water is often supplied from multiple water sources including public water supply and harvested rainwater as well as licensed direct abstraction from surface and groundwater. Although more expensive, public water supply provides greater control over irrigation water quality and flexibility to switch or supplement water from other sources during times of shortage. The factors influencing water demand are quite different (Morris et al., 2017). In addition to meeting the full crop water requirement, as no rainfall contributes to plant growth, additional water is needed to leach, or wash, salts in order to avoid salinisation of the confined root zones (Phogat et al., 2020).

Not all irrigators are able to meet the theoretical demand, and actual water use is constrained by the availability and reliability of water supply (Rio et al. 2018; Salmoral et al., 2019). The total national water withdrawal depends on the area of cropping (hectares and type of crop irrigated), the water applied per ha and how effectively the farmer uses it, i.e. accounting for 
non-consumptive use between the water source and end use (Daccache et al., 2015; Nair et al., 2013).

\section{Defining a water strategy for agriculture and horticulture}

In England and Wales, all water companies are legally required under the Water Industry Act (1991) to produce a Water Resources Management Plan (WRMP) and to submit these to government for scrutiny (Water UK, 2015). These are used to identify the risks facing individual public water supply companies over the next 25 years and to enable them to set out their strategic investment plans to deliver secure and reliable supplies of water within their resource zone and to cope with population growth, socio-economic development, and climate change within their supply zone (Ives et al., 2018). The WRMPs are updated on a five-year rolling cycle to incorporate policy changes and better understanding of the external drivers of change including climate uncertainty. Water companies also need to strike a socially and economically acceptable balance between the frequency and likelihood of future drought shocks on their supply-demand balances and infrastructure, the consequences of regulatory interventions (e.g. hose pipe bans, temporary use bans, restrictions), and the costs of implementing additional supply and/or demand management measures to reduce exposure to risk and supply failure (Kingsborough et al., 2016). The WRMP approach constitutes a wellestablished, repeatable and transparent approach that is used by all water companies, scrutinised by government and widely recognised by the water industry and its stakeholders as being a robust approach to help build systemic resilience and plan for future climate and water-related risks in the water industry.

In the absence of a water strategy for agriculture, we argue that the underlying WRMP approach is an appropriate framework to similarly plan for the future. Specifically, the WRMP rationale can help to define a water strategy for irrigated agriculture and horticulture including identifying the key risks and priorities for action. Through extensive liaison with the UK agricultural and horticultural community, including meetings with key informants, grower workshops, and engagement with industry and stakeholder organisations (including the National Farmers Union, NFU, Environment Agency, and the levy board Agriculture and Horticulture Development Board, AHDB), three strategic themes were defined: (i) managing irrigation 'hotspots' and forecasting demand, (ii) addressing regulatory and environmental challenges linked to a changing climate, and (iii) working together to build resilience to climate and water risks. These three themes resonate with the WRMP approach water companies use to provide rigour and flexibility to cope with future water risks as they have to (i) understand current water demands and future supply-demand imbalances (ii) assess the environmental challenges due to population growth and climate change, (iii) build resilience into their water infrastructure and supply networks, and (iv) address consumer needs and customer affordability. They also resonate with the current plans to develop an integrated approach to water resources planning and management for England (EA, 2020). Previous plans focused only on public water supply and the environment.

\section{Vision and guiding principles}

For agriculture, the high-level vision should support economic growth and increase food security in the UK, secure a fair share of water and recognise that agriculture is an 'essential' use, protect appropriate levels of licensed headroom in future allocations for drought resilience, and share risks and benefits in water supply investments by fostering multi-sector collaboration with public water supply, energy, and environment sectors. It should also drive improvements in water productivity $\left(\mathrm{t} / \mathrm{m}^{3}\right)$ and water value $\left(£ / \mathrm{m}^{3}\right)$ across the various subsectors within agriculture and horticulture, support improved knowledge translation to 
increase resilience to climate and water risks, and drive innovation in precision water management to improve irrigation efficiency.

Despite regional disparities in the dependence on water for agriculture, any strategy should also be national in scope and focus on both outdoor field-scale cropping and indoor (protected) production. It should also define the entry points where action is required, in this case with a focus 'on-farm' and excluding water-related risks in the value chain (post farmgate) in the packing, processing and supply chains. This does not mean these are not relevant but rather the priority is to focus on primary production since it is more vulnerable to disruptions in water supply through abstraction restrictions.

A water strategy would therefore represent the logical progression towards supporting irrigation abstraction in water-stressed catchments, recognising its importance to sustaining the rural economy, livelihoods and the farming landscape, and its role in providing substantial volumes of produce to the agrifood and drinks industry. The strategy needs to recognise that freshwater resources are limited, particularly in the drier parts of the country, where opportunity costs are high, and where water for agriculture is in competition with demands from public water supply, industry, power generation and the environment. A summary of each theme, including the key issues and priorities for action is given below.

\section{Managing irrigation hotspots and forecasting demand}

\section{Underlying trends in irrigation demand}

Although the demand for irrigation is expected to increase over the next few decades, since 1990 irrigation abstractions (volumetrically) have been falling. This is in response to new licences having 'hands-off flow' conditions, increased energy costs for pumping, increased efficiency, and changes in cropping. For example, the consumption of fresh potatoes in the UK halved between 1981 and 2010, which has reduced the area of potatoes being grown (Potato Council, 2012) and hence irrigation demand. But the nature and distribution of irrigated production is also changing, with increased emphasis on quality assurance and greater reliance on irrigation, particularly for short-season, shallow-rooting speciality vegetable and salad crops and soft fruit (strawberries). Recent dry years and the 2018 drought have also highlighted the risks to rainfed cropping in a humid climate, with many businesses investing in new irrigation infrastructure (including on-farm reservoir storage and/or improved application and distribution systems) to cope with increased rainfall uncertainty and higher peak demands for irrigation.

\section{Identifying irrigation 'hot-spots'}

Irrigation abstractions vary from year to year depending on summer rainfall, but there are 'hotspots' where catchments are already water-stressed and where abstraction for irrigation is most intense. Over half of all potato, vegetable and fruit holdings (in England and Wales) are located in catchments which are classified as being either 'over-abstracted' (indicating that existing abstraction is causing unacceptable damage to the environment at low flows) or 'over-licensed' (in which if existing licences were used to their full allocation they could cause unacceptable environmental damage at low flows), although this does not distinguish irrigation abstraction intensity (Hess et al., 2011). The proportion of irrigation water for outdoor crops abstracted from surface water has been steadily reducing from about $63 \%$ in 1982 to $54 \%$ in 2005 reflecting the reducing reliability of surface water abstraction, whilst groundwater abstraction has increased from $30 \%$ to $41 \%$ over the same period, with mains water making up the greater part of the remainder (Weatherhead, 2005). Around a third (29\%) of the total is abstracted during the winter months when river flows and groundwater levels are high, and stored in farm reservoirs ready for use in the summer (Fitzsimons et al., 2019). 
Identifying irrigation hot-spots can help inform future vulnerability assessments and the implementation of strategic measures to mitigate water scarcity on agricultural production (Weatherhead and Howden, 2009). The demand maps and data described above were therefore combined with Environment Agency (EA) spray irrigation abstraction data from their National Abstraction Licensing Database and with the EA's latest estimates of resource availability to identify irrigation intensity $\left(\mathrm{m}^{3} / \mathrm{km}^{2}\right)$ and abstraction 'hot-spots' (Figure 2). These were defined as water resource management units which are most constrained in terms of their resource availability (classified as being 'over-abstracted' (EA, 2002)) and which also had a high intensity of reported spray irrigation abstraction. Irrigation intensity was categorised as being either very high $\left(>10,000 \mathrm{~m}^{3} / \mathrm{km}^{2}\right)$, high $\left(5,000-10,000 \mathrm{~m}^{3} / \mathrm{km}^{2}\right)$ or medium $\left(1,000-5,000 \mathrm{~m}^{3} / \mathrm{km}^{2}\right)$. Irrigation abstractions are highest in East Anglia and Lincolnshire, with pockets of high demand in east and west Midlands and south-east England. Due to the high levels of agricultural and non-agricultural abstraction in these catchments that contribute to the "over-abstracted" status, there is an elevated risk of irrigation being constrained by mandatory abstraction restrictions to protect public water supply and environmental flows during dry years and droughts (Rio et al., 2018; Salmoral et al., 2019). These restrictions can take the form of either licence-specific river flow-based abstraction restrictions (so-called Hands off Flows) or the imposition of catchment-scale drought management restrictions (so called Section 57 restrictions, under the Water Resources Act, 1991). The likelihood of such restrictions being imposed increases with annual irrigation demand due to the conflict between water availability and irrigation need that increases with increasing drought severity / duration. This type of spatial analysis is particularly useful in highlighting areas where competition and conflict for water and pressures on the sustainability of irrigation are most likely to emerge. It can also inform where there is greatest need to desynchronise irrigation demand from environmental demands and summer water availability, particularly in dry years, thus where there can be strong reliability benefits from the construction of on-farm winter storage reservoirs (Holman and Trawick, 2011).

\section{Forecasting demand}

Unlike trends in public water supply, predicting future water demands for agriculture is fraught with difficulties (Knox et al., 2018a). Crop and climate matter, but projections are highly sensitive to a number of inter-linked factors, including agro-economic and food policy (e.g. government decisions relating to national food security, self-sufficiency, dependence on imports) diets (Hess et al., 2016), changing environmental regulations (Bateman and Balmford, 2018), the impacts of socio-economic development and climate change (Weatherhead et al., 2015; Knox et al., 2010). The relative importance of these factors, and how they combine to impact on water demand, is complex. Changes in agro-economic policy and government decisions regarding trade tariffs (Swinbank, 2019) and levels of selfsufficiency can have dramatic short-term impacts. Each factor or 'driver of change' therefore requires careful scrutiny to assess both their relative importance and how they might change in the future.

Although demand forecasting has been periodically undertaken over the last 25 years for outdoor irrigated agriculture, unfortunately, for protected edibles and ornamentals much of the base data and equivalent analysis is not yet available. The increasing diversity in outdoor cropping also necessitates regular projections of irrigation demand. The UK decision to leave Europe will mean previous demands forecasts ignore the implications of potentially profound changes in agro-economic policy.

For protected horticulture, marginal increases in demand are likely due to increased temperatures. The overall cropped area could also increase due to population growth and 
rising consumer demand for soft fruit associated with health benefits (Hess et al., 2015). However, in contrast to outdoor irrigated agriculture and horticulture, there are no reported studies on the likely direction and magnitude of change in water demand for this sub-sector in response to future socio-economic development, or changes in climate or horticultural policy. Key uncertainties for the sector include (i) the trade and tariff effects on levels of production post-Brexit (arising from changes in e.g. Dutch imports), (ii) future changes in abstraction licensing and reductions in headroom, (iii) ) the reliability of public water supplies and classification of 'non-essential use' (with many water companies striving to reduce high levels of 'discretionary use' following the 2018 drought), (iv) increased summer weather variability linked to climate change, (v) changes in gardening habits linked to home fruit and vegetable production and lifestyles (influenced by attitudes towards gardening and garden size for new housing developments) and diets (consumer demands for locally produced vegetables, soft fruit and salad crops).

Factors influencing water demand for outdoor irrigated agriculture and protected horticulture are given in Tables 2 and 3, respectively and in Figure 3. Despite the complexities of forecasting demand and the unknowns, planners require estimates of future needs based on current knowledge. Table 1 summarises the current reported 'best estimates'.

\section{Addressing regulatory and environmental challenges linked to a changing climate}

A number of significant water and environmental regulatory changes are underway which, coupled with changes in agro-economic policy, will have profound consequences for agricultural irrigation (Lange and Shepheard, 2014; Lumbroso et al., 2014). The fundamental questions are how such changes in water allocation and environmental management will impact irrigation and what actions are needed to ensure the sector remains economically viable whilst minimising its environmental impact.

\section{Ameliorating the environmental impacts of irrigated production}

Although irrigation has long been practised, in the past 20 years or so, the range of crops being grown, the methods of irrigation, the amounts of water applied, and the areas of land irrigated have all been changing. Some historically rainfed crops are now irrigated. Irrigation is no longer a low-cost marginal activity but an essential component of production to 'add value'. This has led to increased abstraction in some catchments. Agricultural water abstraction has been identified as the reason for the deterioration of six water bodies in England between 2009 and 2015 and of 81 water bodies being unable to reach good status under the European Union's Water Framework Directive (Environment Agency, 2015). Although there is no differentiation of irrigation abstraction within the statistics, it is likely to be a significant pressure in many of these cases due to its consumptive nature, the timing of peak irrigation demand and its inverse relationship with water availability Added to this are potential impacts on aquatic ecosystems and protected habitats. Environmental threats include over-abstraction of groundwater, salinisation, and nutrient leaching and soil erosion in areas of intensive irrigated agriculture (Goulding, 2000). Although legislation is in place to protect the aquatic environment, the conflicting interests of environment versus irrigated agriculture are likely to become more widespread and pronounced in future (Knox et al., 2012).

A range of possible measures are available, with some being more technically focussed including the implementation of precision irrigation technologies such as variable rate irrigation (El Chami et al., 2019; Daccache et al., 2015), or improved irrigation scheduling (Hess, 1999). However, the unpredictable nature of rainfall in the UK challenges precision irrigation, both in terms of space and time. The spatial variability of soil water, and therefore plant stress, is reduced when rain falls during the growing season, therefore investment in 
precision application only generates returns in dry years (Pérez-Ortolá et al., 2015). Irrigation scheduling techniques, based on real-time observations of soil water or plant status can be inefficient if rain falls within a few days of irrigating. Increased skill of short range weather forecasts would provide farmers and growers with the knowledge to adjust irrigation schedules to maximise rainfall utilisation and reduce irrigation need (Dorling, 2014).

Others approaches are more socio-technical in nature (fostering collaborative partnerships, water user associations) or are location specific. Many of the initiatives are contingent on the water regulatory framework and therefore involve some policy changes and adjustments to the institutional management and governance of water at national and regional levels (Lumbroso et al., 2014). For example, water sharing has been identified as a potential solution to address surface water constraints for irrigated agriculture in a selected catchment but concerns regarding what is legally possible within existing regulation is hampering progress (Lui et al., 2020). Different interventions could deliver similar beneficial outcomes, depending on the policy mix and how innovations in technology and management are promoted and implemented on-farm. The current debate is over reconciling the national priority and balance between environmental protection and food security. It is a complex issue because of the changing nature of our environment, and public concerns to secure sufficient, high-quality food at an affordable price, whether home grown or imported, and the impact this has on the wider agrifood industry.

\section{Improving drought risk management on-farm}

Most farmers are well attuned to managing short-term weather-related crop risks, but the key to reducing drought risk on farms is to improve how farmers manage the uncertainty of rainfall and water availability in line with cropping requirements and the markets. One practical outcome from recent research following the 2011-2012 drought was D-Risk. This is an intuitive web-based tool to help farmers understand their current and emergent drought and irrigation abstraction risks to support more robust decision-making when changing cropping plans and investing in water infrastructure. Data inputs include crops and areas irrigated, soil types, annual licensed volumes, water sources, and peak abstraction limits. D-Risk then provides the farmer with two important metrics - a probabilistic assessment of how likely they might experience an irrigation deficit, and how their licensed 'headroom' might change. This provides farmers with a detailed understanding of how future changes in crop mix and/or area might change their drought risk profile; or how any reductions in licensed allocation might impact on their business (Haro-Monteagudo et al., 2019). Readers interested in D-Risk are referred to www.d-risk.uk. Building on D-Risk, a follow-on project aims to develop a tool to evaluate the joint risks of abstraction restrictions (voluntary and mandatory) when there are constraints on water availability and insufficient licensed volumes during drought events. It will also improve decision-making in support of local scale initiatives for water trading or sharing.

One other key aspect is assessing the investment need for reservoir storage to offset shortterm drought impacts on direct abstraction. In the UK, all abstractions for irrigation since the Water Resources Act (1963) came into force are licensed by the EA who distinguish "spray irrigation - storage" as a separate use category. Fitzsimons et al (2019) reported that nationally, nearly a third (29\%) of recent (2010-2015) abstractions for spray irrigation were for storage, rising to $44 \%$ in Eastern England. There is also a strong correlation between the location of storage licenses and restricted resource availability with a high proportion of storage licenses within catchments defined as being either over-abstracted and/or overlicensed (Weatherhead et al., 2014). An analysis of the EA data shows that, by number, nearly half the storage licences are located in Anglian Region (46\%) which account for two thirds 
$(66 \%)$ of the total licensed volume. Weatherhead et al (2008) that over half of all licences $(53 \%)$ were for under $25,000 \mathrm{~m}^{3} /$ year, and a further quarter were for reservoir capacities of between 25,000 and $50,000 \mathrm{~m}^{3} /$ year.

Reductions in summer water reliability coupled with contractual retailer pressures means many businesses are switching to reservoirs as their preferred on-farm adaptation strategy to drought. Whilst most farming enterprises recognise the business benefits of storage reservoirs, they need to justify the high capital investment costs and set these against potential future changes in winter (high flow) water availability and their cropping plans. Using key informant interviews, a detailed analysis of both farmer and engineering perspectives on the constraints to reservoir development was reported by Weatherhead et al. (2014). Obtaining the capital to meet the overall cost was ranked as the largest single constraint, with the costs of technical studies and engineering design, obtaining planning permission, and the costs of environmental studies (all of which are incurred irrespective of whether or not the reservoir can be built) also highlighted as major barriers. From the design engineers' perspective, the difficulties in obtaining planning permission and increasing demands for funds for environmental and archaeological studies (both issues largely out of their control) were cited.

\section{Regulatory challenges}

Many catchments in which irrigation is concentrated are already over-abstracted and/or overlicensed. Abstraction reform seeks to ensure that all catchments are environmentally sustainable. A range of measures including voluntary revocation of unused licences, reducing headroom on what are considered to be under-utilised licences, and facilitating simple water trading arrangements to support economic growth have all been proposed. But abstraction reform must be supported by evidence-based assessments of water need and reliability, particularly during droughts when the responses to irrigation and environmental risks are highest. At present no tools exist to support dialogue between the regulatory agencies with abstractor groups about water needs, and for farming businesses trying to assess their abstraction reliability due to drought restrictions.

\section{Economic instruments to improve resource allocation and use}

In some semi-arid regions (e.g. parts of Australia), economic instruments including water trading have been actively pursued in an attempt to drive up water efficiency and reallocate water use away from lower-value agriculture to high-value horticultural production (Arcadis, 2012). In the UK, formal water trading of abstraction licenses between individual farm businesses has not materialised, despite a willingness by the regulatory authority to support such an initiative. This has largely been down to industry criticisms regarding the existing regulatory framework lacking sufficient flexibility to deal with short-term trades and the slow speed of transactions (recognising that short-term droughts, lasting only a few weeks, are more common in the UK). In contrast, informal water sharing arrangements (including renting land with a licensed allocation of water for the cropping season) are widely practiced, building on trusted relationships between farmers and offering a greater degree of business flexibility. Indeed, Lui et al (2020) found that, in a water abstractors group, water sharing was the preferred option as an adaptation response to cope with future increases in drought risk and/or summer abstraction restrictions. Aligned with this approach at local level are more regional-scale collaborative actions to support integrated water resources management and specifically to foster multi-sector engagement to identify opportunities for shared infrastructural investment. These could include, for example, large storage reservoirs where multiple benefits could be accrued for both domestic water supply, agricultural irrigation, environment enhancements, leisure and amenity. This would also provide an opportunity to influence the new UK government Environmental Land Management Scheme (ELMS) which 
will pay farmers for environmental services and benefits, with pricing based on a natural capital valuation (Defra, 2020b). This would support farm revenues whilst building natural capital and increasing the flow of ecosystem services from water dependent habitats.

\section{Working together to build resilience to climate and water risks}

Recent experiences from the 2018 drought, concerns linked to regulatory reform and regional pressures and competition for water among all sectors, are encouraging water users to work together. There will be a need to forge new relationships and to strengthen collaboration between agriculture and other sectors (Whaley and Weatherhead, 2015a). Historically, water resources planning in the UK has focused on securing public water supply and protecting the environment, while water demands for agriculture were overlooked. When water is in short supply, agriculture has been first to experience restrictions. This approach to water allocation has served well in the past, when in most years there has been a plentiful supply of water. But rising demand for water is resulting in increased competition for the available water supply, particularly during droughts. Priorities will still apply but, increasingly, allocation decisions can no longer be made in isolation without regard to other users. A more integrated and transparent approach is essential for water resources planning to take account of all water users. This resonates with experiences in other countries experiencing water scarcity and the need for integration and water sharing (UN, 2018).

As water risks within particular regions become more acute there is an urgent need for multistakeholder platforms to represent and engage the interests of all water users, to provide a mechanism for discussion and scrutiny of the water challenges facing businesses, and to create pathways through which new knowledge can be translated. In 2020 the Environment Agency, the regulator for water resources in England, published its National Water Framework (Environment Agency 2020; Harou, 2019). This constituted a major shift in water planning and provides new strategic direction for water resources planning, including users outside the water industry, to support collaboration. This has provided agriculture with an opportunity, particularly in the drier regions, to engage in multi-sector dialogue. In this context, Water Resources East (WRE) is one of the five regions identified in the national water framework and is the most advanced in developing an integrated approach to water resources planning across eastern England, where there is substantial demand for irrigation. WRE is a pioneering programme to promote a multi-sector and collaborative approach to water resource planning, bringing together regulators, business, and researchers in the water, agriculture, power, and environmental sectors (WRE, 2020). Through extensive engagement and advanced modelling, WRE investigated future demands and potential trade-offs across all sectors to identify options to build resilience into regional water resources management and planning. Fundamental to the core vision for WRE was recognising that future water scarcity is a shared problem which needs collaborative solutions.

Specific interest groups form as water issues emerge. Unfortunately, previous attempts to foster collaboration have missed opportunities to build a strategic and joined-up approach to water resources management. However, as the UK government moves towards integrated water resources planning, agriculture must be more proactive in representing its own interests and role in the planning process. The sector has traditionally focused on commodities rather than resources and so its approach to water resources has been fragmented, with sub-sector interests often driving the agenda for action, particularly during periods of resource stress (e.g. drought or regulatory reform).

\section{Power of collaboration}


A coordinated and coherent voice for agriculture is also needed at local (catchment) level. As water scarcity (or the threat or water scarcity) increases, there are greater incentives for individuals to organise and take collective action to defend a 'common good', rather than relying on the actions of individuals (Whaley 2014; Whaley and Weatherhead, 2015b). In response to previous droughts, water abstractor groups (WAGs) have formed in some catchments, bringing farmer interests together to share experiences and defend their right to irrigate, to build more transparent channels of communication between themselves and the regulator, to foster a stronger commitment among their members to use water more efficiently and sustainably, and to provide a strong collective voice to influence future water policy (Leathes et al., 2008; Holman and Trawick, 2011). To date, ten WAGs exist in various forms across the UK (as well as many informal collaborations among neighbouring farming enterprises), but more are needed to bring individual abstractors together to help coordinate and strengthen farmer representation (Whaley and Weatherhead, 2015b) and to identify innovative mechanisms through which water trading or sharing could be implemented at the catchment scale (Liu et al., 2020).

\section{Industry and research priorities for action}

An essential component of any strategy is to identify the key priorities for action. Table 4 summarises a set of proposed actions within each strategic theme, with a distinction also made between those relevant to outdoor irrigated agriculture and protected horticulture. Selected key areas for attention are considered below.

One of the major research challenges in forecasting future agricultural irrigation demands is that modelling relies to a large extent on detailed spatial assessments of the composition of irrigated land use (crop mix) and the proportions of each crop that are irrigated. Current approaches have relied on outdated Defra Irrigation Survey census data (Defra, 2010) and county level data on the proportion of each crop irrigated. The availability of high-resolution land use imagery coupled with data on abstraction returns and possibly information from the levy board (AHDB) on land holdings could be used in future by researchers to derive more accurate temporal and spatial estimates of irrigated area (ha) and the proportions of each crop irrigated $(\%)$.

The protected horticulture sector has repeatedly been excluded from previous demand forecasting studies in agriculture, due to its highly specific composition and unique drivers of change. A number of important research gaps in knowledge exist which need to be addressed. These include collating accurate regional and catchment level data on cropped areas and their spatial extent. National published statistics are too crude for demand forecasting, particularly where enterprises are concentrated in catchments or water resources zones that are water stressed. Updated information on the temporal patterns of water use in the sub-sector including the different sources of water used (direct abstraction, mains water) are also required. Industry information on the future 'drivers of change' and how socio-economic and agro-economic policies are likely to impact on the sub-sector are also required, including the effects of trade and tariffs on imports and likely sector expansion and/or contraction. Understanding the impacts of climate change on the sub-sector, and how this might affect production, the composition of plants offered, and target market are also important research knowledge gaps. For the industry, assessing the impacts of abstraction reform and how this might influence the future choice of water sources and investment options including the viability of rainwater harvesting would be beneficial.

\section{Concluding comments}


Although the UK has a well-developed strategy for public water supplies and is developing a strategy for water and the environment, it has yet to develop a comprehensive water strategy for agriculture. This paper proposes a strategic framework to fill this gap. It is based on major climate, regulatory, and environmental water-related risks, and recognises political and socioeconomic uncertainties facing agriculture and horticulture that impact on water use, and identifies priorities for action from both industry and research perspectives. The strategic framework centres on three thematic areas including (i) managing irrigation 'hotspots' and forecasting demand, (ii) addressing regulatory and environmental challenges linked to a changing climate, and (iii) working together to build resilience to climate and water risks. The strategic themes are intended to provide a focus for concerted and collaborative action with engagement from all those likely to be impacted by future water scarcity including farmers involved in primary production, industry organisations representing the interests of UK agriculture, regulatory agencies, technical advisory services, NGOs, special interest groups, and university and research organisations delivering $\mathrm{R} \& \mathrm{D}$.

Inaction could severely damage the industry, in terms of productivity, sustainability and reputation, and could further fragment and increase vulnerability in the agrifood sector. The risk is that water would be 'traded' out of agriculture leading to business contraction and stagnation and increased conversion from high-value intensive to lower input extensive agricultural systems, resulting in reduced GVA, rural employment, and job security. There would also be substantial lost opportunities for expanding high-value crop production and loss of benefits for the fresh produce value-chain. Finally, there could be increased regional tension and local conflict among competing sectors as pressures on increasingly constrained water supplies arise. Clearly, it is in both the UK's national and industry's interests to avoid such negative consequences. Although this framework was developed for a humid climate, it may have relevance to other temperate and semi-arid countries where agricultural irrigation is a major component of freshwater abstraction but where similar challenges and emergent risks exist. It will be critical for the agricultural sector to rise to the challenge, demonstrate it can drive change within the industry, embrace innovation, and promote more sustainable farming practices that improve water management and reduce its environmental footprint.

\section{Acknowledgement}

This review draws on research outputs from research grants NE/L010070/1 and NE/L010186/1 of the UK Droughts \& Water Scarcity (D\&WS) programme, a Natural Environment Research Council programme in collaboration with other UK Research Councils (Economic and Social Research Council, Engineering and Physical Sciences Research Council, Biotechnology and Biological Sciences Research Council and Arts and Humanities Research Council). The authors acknowledge contributions to this work made by John Adlam and Paul Hammett (NFU) and the many farmers and individuals who attended the project workshops and stakeholder meetings. The authors also thank Dr Nevil Quinn (University of West England) for his support. No new data were collected in the course of this research.

\section{References}

Arcadis (2012) The role of water pricing and water allocation in agriculture in delivering sustainable water use in Europe - Final Report to the European Commission (No 11589). Available at: https://ec.europa.eu/environment/water/quantity/pdf/agriculture_report.pdf

Advisory Committee for Agriculture and Horticulture in England and Wales (1978). Agriculture and the Countryside. Strutt Report (3rd edition), HMSO, London.

Afzal M and Ragab R (2019). Drought Risk under Climate and Land Use Changes: Implication to Water Resource Availability at Catchment Scale. Water 11(9): 1790. 
Barker LJ, Hannaford J, Parry S, Smith KA, Tanguy M, Prudhomme C (2019). Historic hydrological droughts 1891-2015: systematic characterisation for a diverse set of catchments across the UK. Hydrological Earth Systems Sciences 23(11): 4583-4601.

Bateman I and Balmford B (2018). Public funding for public goods: A post-Brexit perspective on principles for agricultural policy. Land Use Policy 79: 293-300.

Burke EJ, Perry RHJ, Brown SJ (2010) An extreme value analysis of UK drought and projections of change in the future. Journal of Hydrology 388 (1-2):131-143.

Daccache A, Knox JW, Weatherhead EK, Daneshkhah A, Hess TM (2015). Implementing precision irrigation in a humid climate - Recent experiences and on-going challenges. Agricultural Water Management 147: 135-143.

Defra (2011) Water for Life. Defra White Paper. HMSO, London. ISBN 9780101823029.

Defra (2019). Abstraction reform report: Progress made in reforming the arrangements for managing water abstraction in England.

https://assets.publishing.service.gov.uk/government/uploads/system/uploads/attachment_data/ file/801495/abstraction-reform-report.pdf

Defra (2020a). Farming for the Future: policy and progress update. Defra report PB 14610. https://assets.publishing.service.gov.uk/government/uploads/system/uploads/attachment_data/ file/868041/future-farming-policy-update1.pdf

Defra (2020b). Environmental Land Management Policy discussion document. Available at https://consult.defra.gov.uk/elm/elmpolicyconsultation/ (accessed 27/07/2020).De Silva, C.S., Weatherhead, E.K., Knox, J.W. and Rodriguez-Diaz, J.A (2007). Mapping the climate change impacts on irrigation water requirements for Maha season paddy rice in Sri Lanka.

Agricultural Water Management 93: 19-29.

Dorling, S (2014) Managing climate variability in agriculture: Using weather forecasting to support farming adaptation. Outlook on Agriculture. 43, 13-18, doi:10.5367/oa.2014.0151.

El Chami D, Knox JW, Daccache A, Weatherhead EK (2019) Assessing the financial and environmental impacts of precision irrigation in a humid climate, Horticultural Science, 46 (1) 43-52.

Environment Agency (2015). Update to the river basin management plans in England: national evidence and data report. Environment Agency, Bristol, UK, pp20. Available from https://www.gov.uk/government/publications/river-basin-management-plans-nationalevidence-and-data-report

Environment Agency (2020). Meeting our future water needs: a national framework for water resources. EA, Bristol. Available from https://www.gov.uk/government/publications/meetingour-future-water-needs-a-national-framework-for-water-resources

Fitzsimons, B., Fraser, A., Ballinger, S., Fischer, S, Knox, JW, Hess, TM (2019).

Understanding future water demand outside of the water industry. Final Report for Defra, Wood Consulting with Cranfield University and Ricardo.

Goulding K (2000). Nitrate leaching from arable and horticultural land. Soil Use and Management 16: 145-151.

Grafton, RQ, Williams, J., Perry, CJ, Molle, F., Ringler, C., Steduto, P., Udall, B., Wheeler, SA, Wang, Y., Garrick, D., and Allen, RG (2018). The paradox of irrigation efficiency. Science Vol. 361, Issue 6404, 748-750.Haro-Monteagudo, D., Knox, JW, Holman, IP (2019) 
D-Risk: a decision-support webtool for improving drought risk management in irrigated agriculture. Computers and Electronics in Agriculture 162: 855-858.

Harou JJ (2019). Towards a national water resources planning framework in England. Proceedings of the Institution of Civil Engineers - Water Management 172(6): 271-272.

Hess TM (1999) Minimising the environmental impacts of irrigation by good scheduling. Irrigation News 28, 3-10.

Hess TM, Andersson U, Mena C, Williams A. (2015) The impact of healthier dietary scenarios on the global blue water scarcity footprint of food consumption in the UK, Food Policy 50 1-10.

Hess TM, Chatterton J, Daccache A, Williams A (2016) The impact of changing food choices on the blue water scarcity footprint and greenhouse gas emissions of the British diet: The example of potato, pasta and rice, Journal of Cleaner Production 112: 4558-4568.

Holman, IP and Trawick P (2011). Developing adaptive capacity within groundwater abstraction management systems, Journal of Environmental Management 92(6), 1542-1549.

Ives, MC, Simpson M, Hall JW (2018) Navigating the water trilemma: a strategic assessment of long-term national water resource management options for Great Britain. Water and Environment Journal 32(4): 546-555.

Kingsborough A, Borgomeo E, Hall JW (2016). Adaptation pathways in practice: Mapping options and trade-offs for London's water resources. Sustainable Cities and Society 27: 386397.

Knox, JW, Rodriguez-Diaz, JA, Weatherhead, EK, Kay, MG (2010) Development of a water strategy for horticulture in England and Wales. Journal of Horticultural Science and Biotechnology 85(2): 89-93.

Knox, JW, Kay, MG, Weatherhead, EK (2012) Water regulation, crop production and agricultural water management - Understanding farmer perspectives on irrigation efficiency. Agricultural Water Management 108: 3-8.

Knox JW, Daccache A, Weatherhead EK, Groves S, Hulin A (2013) Assessing climate and land use impacts on water demand for agriculture and opportunities for adaptation. Phase I Final Report, FFG1129 to Defra.

Knox JW, Rickson RJ, Weatherhead EK, Hess TM, Deeks LK, Truckell IJ, Keay CA, Brewer TR, Daccache A (2015) Research to develop the evidence base on soil erosion and water use in agriculture. Final Technical Report for Committee on Climate Change.

Knox, JW, Haro-Monteagudo, D., Hess, TM, Morris, J (2018a) Identifying trade-offs and reconciling competing demands for water: Integrating agriculture into a robust decisionmaking framework. Earth's Future 6(10): 1457-1470.

Knox, JW, Kay, MG, Holman, IP, Hess, TM (2020) Irrigation water strategy for UK agriculture and horticulture". Booklet published by UKIA and NERC ENDOWS.

Lange B, Shepheard M (2014). Changing Conceptions of Rights to Water?-An Eco-SocioLegal Perspective. Journal Environmental Law 26(2): 215-242.

Leathes, W, Knox, JW, Kay, MG, Trawick, P, Rodriguez-Diaz, JA (2008) Developing UK farmers' institutional capacity to defend their water rights and effectively manage limited water resources. Irrigation and Drainage 57(3): 322-331. 
Liu D, Long' Or Lokidor P, Rushen K, Sanchez J, Zylberman R (2020) Improving water resources abstraction management for agricultural and environmental needs in the River Lark catchment. Group Project report for the River Lark Catchment Partnership. Cranfield University.

Lumbroso DM, Twigger-Ross C, Raffensperger J, Harou JJ, Silcock M, Thompson AJK (2014). Stakeholders' responses to the use of innovative water trading systems in East Anglia, England. Water Resources Management 28 (9): 2677-2694.

McCarthy M, Christidis N, Dunstone N, Fereday D, Kay G, Klein-Tank A, Loew J, Petch J, Scaife A, Stott P (2019). Drivers of the UK summer heatwave of 2018. Weather 74(11): 390396.

Met Office (2020) UK regional climates Available online:

https://www.metoffice.gov.uk/research/climate/maps-and-data/regional-climates/index (accessed on Jul 21, 2020).

Morris J, Else MA, El Chami D, Daccache A, Rey D, Knox JW (2017). Essential irrigation and the economics of strawberries in a temperate climate. Agricultural Water Management 194: 90-99.

Nair S, Johnson J, Wang C (2013). Efficiency of irrigation water use: A review from the perspectives of multiple disciplines. Agronomy Journal 105 (2): 351-363.

NFU (2019) Delivering for Britain Food and farming in the Fens

https://www.nfuonline.com/pcs-pdfs/food-farming-in-the-fens_web/

Pérez-Ortolá, M, Daccache, A, Hess, TM, and Knox, JW (2015) Simulating impacts of irrigation heterogeneity on onion (Allium cepa L.) yield in a humid climate. Irrigation Science, 33, 1-14.

Phogat V, Mallants D, Cox JW, Simunek J, Oliver DP, Awad J (2020). Management of soil salinity associated with irrigation of protected crops. Agricultural Water Management 227: UNSP 105845.

Potato Council (2012). Production and price trends 1960-2011. Agriculture and Horticulture Development Board (AHDB).

Rahiz M and New M (2013). $21^{\text {st }}$ Century drought scenarios for the UK. Water Resources Management 27(4): 1039-1061.

Rey, D., Holman, I.P., Daccache, A., Morris, J, Weatherhead, E.K., Knox, J.W. (2016) Modelling and mapping the economic value of supplemental irrigation in a humid climate. Agricultural Water Management 173: 13-22.

Rey, D., Holman, IP, Knox, JW (2017) Developing drought resilience in irrigated agriculture in the face of increasing water scarcity. Regional Environmental Change 17(5): 1527-1540.

Rio M, Rey D, Prudhomme C, Holman IP (2018). Evaluation of changing surface water abstraction reliability for supplemental irrigation under climate change. Agricultural Water Management 206: 200-208.

Rodriguez-Diaz, J.A., Weatherhead, E.K., Knox, J.W. and Camacho, E. (2007). Climate change impacts on irrigation water requirements in the Guadalquivir River Basin in Spain. Regional Environmental Change 7(3) 149-159.

Royal Society (1978) Scientific aspects of the 1975-76 drought in England and Wales, The Royal Society of London. University Press, Cambridge, p 133. ISBN 0854031030. 
Salmoral G, Rey D, Rudd A, de Margon P, Holman IP (2019) A probabilistic risk assessment of the national economic impacts of regulatory drought management on irrigated agriculture. Earth's Future 7(2): 178-196.

Sharmina M, Hoolohan C, Bows-Larkin A, Burgess PJ, Colwill J, Gilbert P, Howard D, Knox JW, Anderson K (2016) A nexus perspective on competing land demands: wider lessons from a UK policy case study. Environmental Science and Policy 59: 74-84.

Swinbank A (2019) Agriculture and Brexit Britain's 'No-deal' Tariff Plans. Eurochoices 18(3): 4-9.

United Nations (2018) Sustainable Development Goal 6: Synthesis Report 2018 on Water and Sanitation. New York. Available at: https://www.unwater.org/publication_categories/sdg-6synthesis-report-2018-on-water-and-sanitation/

Water UK, 2015. Water Resources long-term planning framework (2015-2065).

WfFG (2018) The case for prioritising water for food production as an 'essential' need. Water for Food Group. Available at: https://www.fdf.org.uk/responses/Essential-needposition-statement.pdf.

Water Resources East (2020). Collaborating to secure Eastern England's future water needs: Our initial water resources position statement. Available at: $\underline{w w w . w r e . o r g . u k}$

Weatherhead EK (2005). Survey of irrigation of outdoor crops in 2005 - England and Wales. Unpublished report for Defra.

https://dspace.lib.cranfield.ac.uk/bitstream/handle/1826/2867/Survey_of_irrigation_of_outdoo r_crops_in_2005-England_and_Wales2007.pdf;jsessionid=A93B0EF27371F2994DADCC469F9A638F?sequence $=1$

Weatherhead, EK, Knox, JW, and Kay, MG (2008) Thinking about an irrigation reservoir? Technical Report to EA.Weatherhead EK and Howden NJK (2009). The relationship between land use and surface water resources in the UK. Land Use Policy 26: S243-S250.

Weatherhead, EK, Knox, JW, Daccache, A., Morris, J., Groves, S., Hulin, A., Short C and Kay, MG (2014) Water for agriculture: collaborative approaches and on-farm storage. FFG1112 Final Report to Defra.Weatherhead, EK, Knox, JW, Hess, TM, Daccache, A (2015) Exploring irrigation futures - developments in demand forecasting. Outlook on Agriculture 44(2): 119-126.

Whaley L (2014) Agriculture and water: emerging perspectives on farmer cooperation and adaptive co-management. Outlook on Agriculture 43(4): 229-233.

Whaley L and Weatherhead EK (2015a). Competition, conflict, and compromise: Three discourses used by irrigators in England and their implications for the co-management of water resources. Water Alternatives 8(1): 800-819.

Whaley L and Weatherhead EK (2015b). Using the politicized institutional analysis and development framework to analyse (adaptive) co-management: farming and water resources in England. Ecology and Society 20(3): 43.

Wilhite D (2007) Preparedness and coping strategies for agricultural drought risk management: recent progress and trends. In: Sivakumar MVK, Motha RP (eds) Managing weather and climate risks in agriculture. Springer, New York, pp 21-38. ISBN 978-3-54072744-6. 
Wreford, A and Adger WA (2010) Adaptation in agriculture: historic effects of heatwaves and droughts on UK agriculture. International Journal of Agricultural Sustainability 8 (4), 278-289. 
Table 1 Recognising the value and importance of water for outdoor agricultural field cropping and protected horticulture (Source: Knox et al., 2020).

\begin{tabular}{|c|c|c|}
\hline Metric & Outdoor field-crops & Protected edibles and ornamentals \\
\hline $\begin{array}{l}\text { Production area } \\
\text { (ha) }\end{array}$ & $\begin{array}{l}\text { In a dry year, outdoor irrigated } \\
\text { cropping accounts for } \sim 150,000 \text { ha }\end{array}$ & $\begin{array}{l}\text { Total area of glasshouses in } 2018 \text { was } \\
2,894 \text { ha. Ornamentals sector covers } \\
\sim 11,800 \text { ha }\end{array}$ \\
\hline Water use $\left(\mathrm{Mm}^{3}\right)$ & $\begin{array}{l}\text { Annual spray irrigation demand in } \\
\mathrm{E} \& \mathrm{~W} \text { ranges between } 82 \text { and } 110 \\
\mathrm{Mm}^{3} \text {. Theoretical (unconstrained) } \\
\text { demand is nearer to } \sim 200 \mathrm{Mm}^{3}\end{array}$ & $\begin{array}{l}\text { Total water use for protected edibles } \\
\text { and ornamentals is between } 17 \text { and } 25 \\
\mathrm{Mm}^{3}\end{array}$ \\
\hline Value $(£)$ & $\begin{array}{l}\text { Annual net benefit of irrigation in a } \\
\text { 'design' dry year* is } \sim £ 665 \text { million in } \\
\text { England and Wales. Average } \\
\text { irrigation productivity }>£ 3.30 / \mathrm{m}^{3}\end{array}$ & $\begin{array}{l}\text { No data available on average } \\
\text { productivity values, but protected } \\
\text { cropping value is } \sim £ 1.4 \text { billion }\end{array}$ \\
\hline $\begin{array}{l}\text { Key production } \\
\text { areas }\end{array}$ & $\begin{array}{l}\text { Cambridgeshire, Essex, Hampshire, } \\
\text { Hereford and Worcestershire, Kent, } \\
\text { Lincolnshire, Norfolk, } \\
\text { Nottinghamshire, Suffolk, and South } \\
\text { Yorkshire }\end{array}$ & $\begin{array}{l}\text { Bedfordshire, Hampshire, } \\
\text { Hertfordshire, Humber, East and West } \\
\text { Sussex, Kent, Lincolnshire, and South } \\
\text { Yorkshire. Smaller pockets in } \\
\text { Cheshire, Hereford and } \\
\text { Worcestershire, and Lancashire }\end{array}$ \\
\hline
\end{tabular}

* In irrigation terms, the 'design' dry year equates to a year with an $80 \%$ probability of non-exceedance.

Table 2 Factors influencing water use in agricultural irrigation.

\begin{tabular}{lll}
\hline Factor & Description & Effect on water use \\
\hline Cropping & $\begin{array}{l}\text { Area and type of crops } \\
\text { grown }\end{array}$ & $\begin{array}{l}\text { As irrigation is expensive (compared to rainfall), it is } \\
\text { concentrated on high value water sensitive agricultural and } \\
\text { horticultural crops. Changes in the area grown of key } \\
\text { irrigated crops will have a large impact on water demand. }\end{array}$ \\
\hline $\begin{array}{lll}\text { Irrigation } \\
\text { demand per } \\
\text { ha }\end{array}$ & $\begin{array}{l}\text { Irrigation demand (in a } \\
\text { dry year) } \mathrm{m}^{3} / \text { ha for a } \\
\text { given crop type, soil } \\
\text { type and location }\end{array}$ & $\begin{array}{l}\text { As irrigation is supplementary to rainfall, the crop demand } \\
\text { for water depends on the timing and distribution of summer } \\
\text { rainfall and any deficit. The greater the deficit, the higher } \\
\text { the irrigation need. }\end{array}$ \\
\hline $\begin{array}{l}\text { Irrigation } \\
\text { efficiency }\end{array}$ & $\begin{array}{l}\text { Losses of water } \\
\text { between source and } \\
\text { crop use }\end{array}$ & $\begin{array}{l}\text { On-farm irrigation systems, as for domestic water systems, } \\
\text { are subject to losses and waste through leaks and } \\
\text { particularly runoff and drainage losses. Reducing losses can } \\
\text { reduce water demand. The method of application and its } \\
\text { efficiency and how it is managed (scheduled) also affects } \\
\text { the gross amount of water required. }\end{array}$ \\
\hline
\end{tabular}


Table 3 Factors influencing water use in the protected edibles (PE) and protected ornamentals (PO) horticulture sector.

\begin{tabular}{|c|c|c|}
\hline Factor & Description & Effect on water use \\
\hline $\begin{array}{l}\text { Cropped } \\
\text { area and } \\
\text { type }\end{array}$ & $\begin{array}{l}\text { Area of crops } \\
\text { cultivated and } \\
\text { range of crop } \\
\text { types grown }\end{array}$ & $\begin{array}{l}\text { For PE, the range of crops grown is unlikely to alter significantly in the short-term due to market demands and supplier } \\
\text { contracts for high quality locally sourced produce. Other high-value niche crops may emerge over time. Water demand is } \\
\text { also a function of cropped area (glasshouses); these are unlikely to fluctuate as much as outdoor crops due to high capital } \\
\text { investment costs. For PO, the range of crops grown is strongly influenced by the retailers. Quality is critical; any defects in } \\
\text { plant quality result in market rejection. }\end{array}$ \\
\hline $\begin{array}{l}\text { Irrigation } \\
\text { demand } \\
\text { per ha }\end{array}$ & $\begin{array}{l}\text { Irrigation } \\
\text { demand }\left(\mathrm{m}^{3} / \mathrm{ha}\right) \\
\text { for a given crop } \\
\text { type and } \\
\text { growing media }\end{array}$ & $\begin{array}{l}\text { Irrigation demand is dependent on crop type and growing media. Annual demand does not vary as much as outdoor } \\
\text { production since crop water requirements need to be fully met from irrigation each year. However, it does depend on the } \\
\text { amount of solar radiation received. Humidity control in winter and early spring can moderate water demand. NFT systems } \\
\text { are most water efficient compared to rockwool or soil-based systems. Irrigation needs for PO are also (i) market dependant } \\
\text { on the presentation of the product (quality attributes), and (ii) cropping decisions are determined by the retailers, not the } \\
\text { growers. Any changes in market requirements for particular plant species impact directly on water demands. Non-essential } \\
\text { water use bans or abstraction restrictions have serious implications on water demand for protected cropping systems as they } \\
\text { have very short term (<1 day) buffering capacity. }\end{array}$ \\
\hline $\begin{array}{l}\text { Irrigation } \\
\text { efficiency }\end{array}$ & $\begin{array}{l}\text { Losses of water } \\
\text { between source } \\
\text { and crop }\end{array}$ & $\begin{array}{l}\text { Protected cropping systems are inherently efficient due to the small areas irrigated, high crop value and advanced levels of } \\
\text { management control and application (micro irrigation). Glasshouse systems typically have high water use efficiency, with } \\
\text { crop transpiration accounting for } 75-95 \% \text { of total water use. However, all systems incur losses through controlled run-off } \\
\text { and drainage to avoid the build-up of salts in the rootzone, particularly in media or rockwool systems. Concerns regarding } \\
\text { disease risk from recirculated water systems collecting/treating drainage runoff or from rainwater harvesting systems have } \\
\text { limited their uptake in the sector. Water costs are a small proportion of total costs so incentives to save water or improve } \\
\text { efficiency are driven by improving nutrient use efficiency and reducing energy costs rather than reducing water use. Drip } \\
\text { irrigation is the norm for most PO particularly for larger pot production, moving away from micro-sprays and mini } \\
\text { sprinklers. Mains water substitution is becoming more widespread as growers attempt to reduce water costs and move } \\
\text { towards self-contained supply systems (rainwater harvesting with direct abstraction or de minimis abstraction). }\end{array}$ \\
\hline $\begin{array}{l}\text { Market } \\
\text { demands }\end{array}$ & $\begin{array}{l}\text { Weather, } \\
\text { holidays, } \\
\text { gardening habits } \\
\text { and lifestyle }\end{array}$ & $\begin{array}{l}\text { Consumer demand for PO is highly dependent on the weather and Public Holidays when a significant share of annual sales } \\
\text { are made. Recent changes in housing policy with more new properties having smaller garden footprints means the } \\
\text { composition of plants grown and marketed has had to change. Smaller gardens with no herbaceous borders means demand } \\
\text { for container or pot-based plants has risen sharply. This is likely to drive up water demand due to pots having lower water } \\
\text { retention media and unable to buffer short-term periods of water deficit unlike natural soils. Demand for certain } \\
\text { ornamentals strongly influenced by exhibitions, including Chelsea Flower Show and celebrity gardener recommendations. }\end{array}$ \\
\hline
\end{tabular}


Table 4 Thematic areas, their identified knowledge gaps and industry (I) and research (R) priorities for action.

\begin{tabular}{|c|c|}
\hline Theme & nowledge gaps and industry/research priorities for action \\
\hline $\begin{array}{l}\text { Managing } \\
\text { irrigation } \\
\text { hotspots and } \\
\text { forecasting } \\
\text { demand }\end{array}$ & $\begin{array}{l}\text { Irrigated areas: Scope to derive accurate estimates of irrigated area and proportions of each crop irrigated by combining high resolution } \\
\text { satellite imagery with abstraction data (R) } \\
\text { Impacts of agro-economic policy on yields and prices: develop revised narratives that describe how national agricultural policies are linked } \\
\text { to food security, self-sufficiency, and agricultural trade (R, I) } \\
\text { Develop demand forecasts that take into account resource availability and reliability at catchment level (I) } \\
\text { Assessment of the impacts of changes in international trade agreements and tariffs on UK field vegetables and salads sector where a large } \\
\text { proportion of UK supply is dependent on EU imports (I) } \\
\text { Catchment data needed on cropped areas, water sources and patterns of water use (R, I) } \\
\text { Drivers of change and policy impacts, including effects of trade and tariffs on imports and sector expansion or contraction (I) } \\
\text { Understanding impacts of climate change and how this may affect production, plants offered, and target markets (I, R) } \\
\text { Assess impacts of abstraction reform and investment options (I) }\end{array}$ \\
\hline $\begin{array}{l}\text { Addressing } \\
\text { regulatory } \\
\text { and } \\
\text { environmental } \\
\text { challenges } \\
\text { linked to a } \\
\text { changing } \\
\text { climate (on } \\
\text { and off-farm) }\end{array}$ & $\begin{array}{l}\text { Development of integrated technologies for precision irrigation, including smart sensor networks and artificial intelligence (R) } \\
\text { Promote uptake of new tools and technologies to improve irrigation management (scheduling) including weather forecasting (I) } \\
\text { Support farm-level initiatives to increase water storage (whether individual or shared) (I) } \\
\text { Support more flexible collaborative approaches (including trading) that make best use of existing resources (R, I) } \\
\text { Support ongoing initiatives to foster multi-sector engagement to identify opportunities for shared infrastructure investment (I) } \\
\text { Develop catchment-based approaches to improve water use and allocation in agriculture (R, I) } \\
\text { Case studies to highlight how improved irrigation scheduling can reduce nutrient leaching risks (R) } \\
\text { Build ecological resilience in river systems through river restoration to reduce drought impacts (R) } \\
\text { Support farmer-focused initiatives in EA priority catchments (I) } \\
\text { Near real-time river flow information to enable farmers to know when to take advantage of short duration high flows to refill reservoirs, or } \\
\text { prior knowledge of likely low flows (R) }\end{array}$ \\
\hline $\begin{array}{l}\text { Working } \\
\text { together to } \\
\text { build } \\
\text { resilience to } \\
\text { climate and } \\
\text { water risks }\end{array}$ & $\begin{array}{l}\text { Support regional-level measures for businesses to work together to reduce drought impacts on agriculture and the environment (I) } \\
\text { Identify actions to foster stronger multi-sectoral collaboration, such as sharing data, access to improved weather forecasts, devolved } \\
\text { responsibilities for catchment-scale water management, and trading portals (I) } \\
\text { Identify measures to enable the agricultural sector to engage with other sectors to reduce vulnerability to climate and water risks (R) } \\
\text { Identify existing gaps in understanding including data needs, information, and evidence to underpin implementation of this strategy, and } \\
\text { agree on how these gaps should be addressed, including funding and delivery mechanisms (I) } \\
\text { Support case studies, policy briefings and Knowledge Transfer Partnerships (KTPs) to foster industrial-research collaboration (R, I) } \\
\text { Identify where and how agricultural abstractors can usefully engage and contribute to local initiatives, including catchment-based } \\
\text { approaches and river partnerships (R, I) }\end{array}$ \\
\hline
\end{tabular}


Figure 1 Assessing relative differences in aridity between selected years using potential soil moisture deficit (PSMD) as an agroclimate indicator.

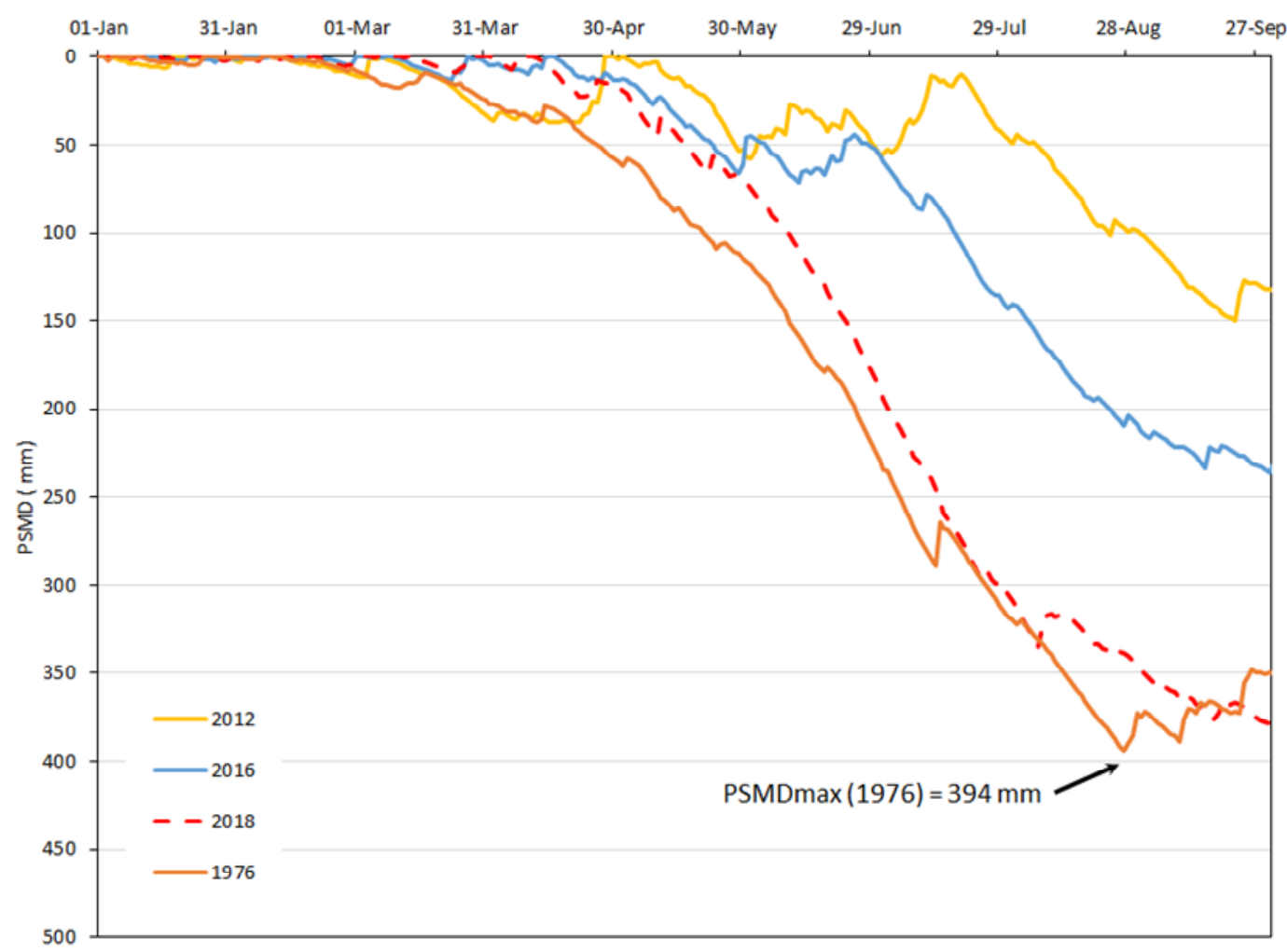


Figure 2 Irrigation intensity $\left(\mathrm{m}^{3} / \mathrm{km}^{2}\right.$ ) (a) and irrigation 'hot-spots' (b) in England and Wales based on Environment Agency abstraction data (2010) and water resource availability (2002). Source: Knox et al (2015).
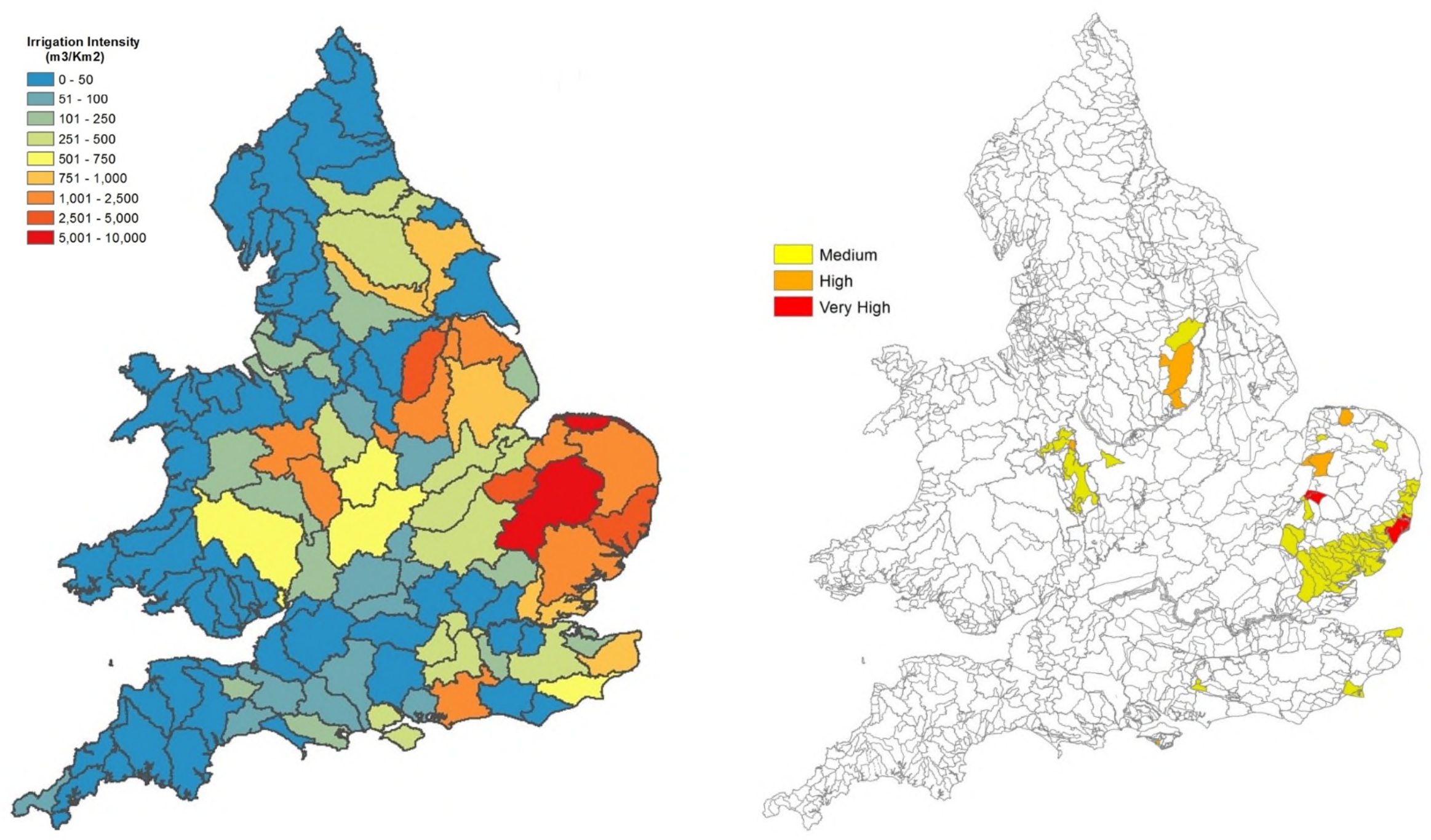
Figure 3 Schematic representation of the factors affecting water use in (a) outdoor agricultural irrigation and (b) protected horticulture (Source: Fitzsimons et al., 2019).

(a) Outdoor agricultural irrigation

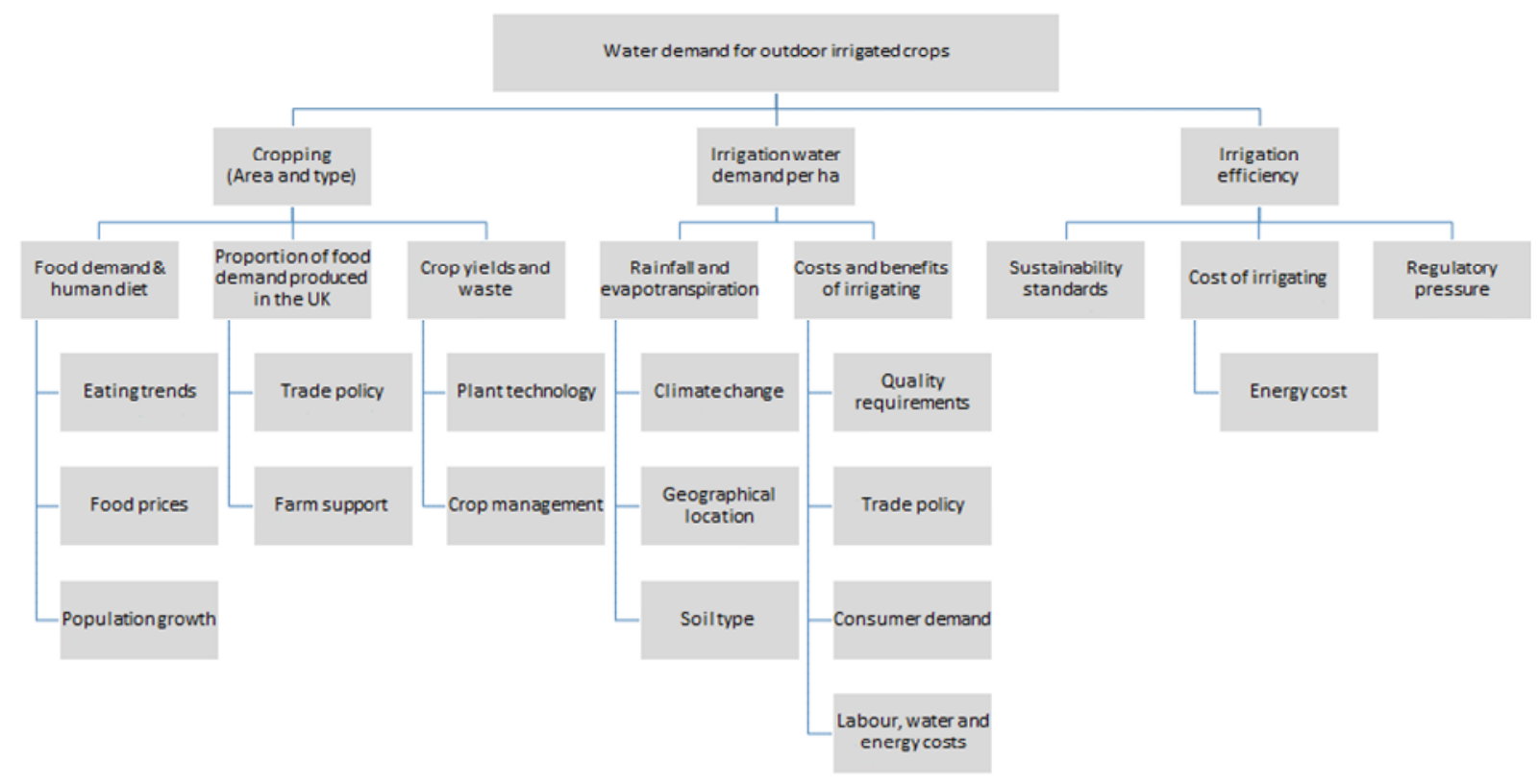

(b) Protected horticulture

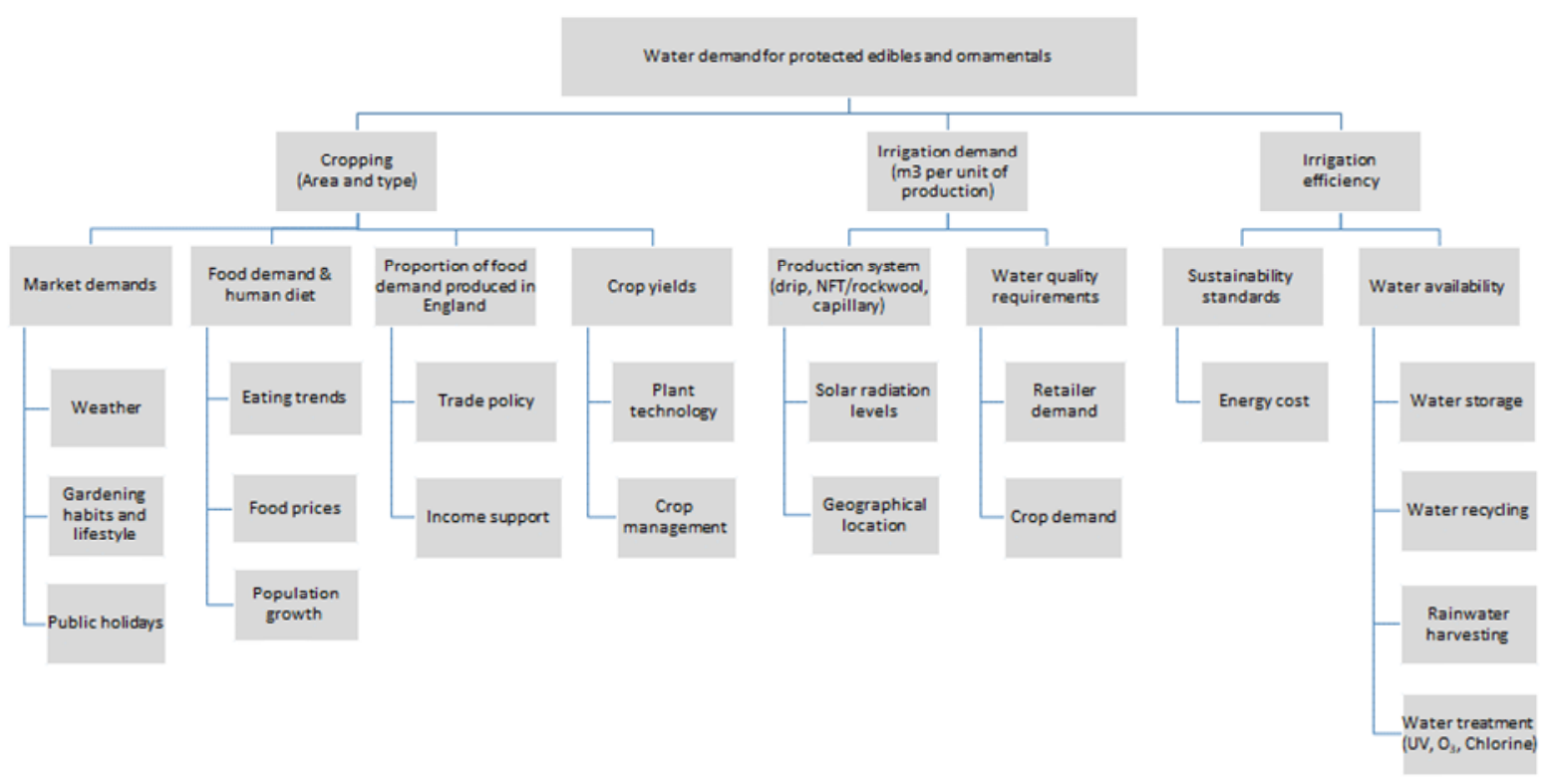

